\title{
PENGARUH KECERDASAN NUMERIK DAN KONSEP DIRI TERHADAP MOTIVASI BERPRESTASI MATEMATIKA
}

\author{
Zikriah \\ Program Studi Informatika Universitas Indraprasta PGRI \\ Email : qie.zikriah80@gmail.com
}

\begin{abstract}
Abstrak
Tujuan penelitian ini adalah untuk menganalisis pengaruh kecerdasan numerik dan konsep diri terhadap motivasi berprestasi matematika. Metode yang digunakan dalam penelitian ini adalah metode survai. Sampel penelitian diperoleh melalui Multi Stage Random Sampling berjumlah 94 siswa kelas IX SMP Swasta di kecamatan Tebet, Jakarta Selatan. Analisa data dilakukan melalui statistik Regresi ganda. Hasil penelitian adalah : (1) Terdapat pengaruh langsung yang signifikan persepsi atas kecerdasan numerik siswa terhadap motivasi berprestasi matematika. (2) Terdapat pengaruh langsung yang signifikan persepsi atas konsep diri siswa terhadap motivasi berprestasi matematika. (3) Terdapat pengaruh secara bersama-sama yang signifikan persepsi atas kecerdasan numerik siswa dan konsep diri siswa terhadap motivasi berprestasi matematika.
\end{abstract}

Kata Kunci: kecerdasan Numerik, konsep diri dan motivasi berprestasi Matematika.

\section{Abstract}

The purpose of this research is to analyze the effect of numerical intelligence and self-concept on mathematics achievement motivation. The method used in this research is a survey method. The research sample is selected through Multi Stage Random Sampling totaling 94 students in grade IX of private Junior High School (SMP) in Tebet subdistrict, South Jakarta. Data analysis is made by using multiple regression statistics. The results of the research are: (1) There is a directly significant effect of student's numerical intelligence on mathematics achievement motivation. (2) There is a directly significant effect on student's self-concept on mathematics achievement motivation. (3) There is a jointly significant effect of student's numerical intelligence and student's self-concept on mathematics achievement motivation.

Keywords: Numerical intelligence, self-concept and mathematics achievement motivation.

\section{PENDAHULUAN}

Matematika adalah induk ilmu pengetahuan yang dibangun dari pengembangan konsep dasar menjadi bentuk yang lebih kompleks melalui penalaran dan kemampuan menganalisa masalah dengan mengkaitkan masalah pada konsep yang telah diakui kebenarannya. Kegagalan menguasai konsep dasar akan berpengaruh pada penguasaan konsep lanjutan. Matematika merupakan salah satu sarana untuk meningkatkan daya nalar siswa, karena didalam matematika terdapat berbagai macam perhitungan-perhitungan selogis (artinya : kemampuan berpikir seperti penjumlahan, pengurangan, pembagian dan perkalian dan juga dapat meningkatkan kemampuan dalam mengaplikasikan matematika). Untuk menghadapi tantangan hidup dalam memecahkan masalah karena dalam matematika siswa dilatih untuk dapat berpikir kritis (artinya : kemampuan berpikir untuk memecahkan berbagai masalah yang ditemui dengan analisis yang mendalam dan teliti), berpikir logis (artinya : kemampuan berpikir dengan lebih menggunakan akal budi dan perhitungan-perhitungan yang matang), berpikir sistematis (artinya : kemampuan berpikir secara bertahap dan berkesinambungan, mulai dari hal-hal yang sederhana sampai kompleks).

Namun banyak anak-anak mengeluhkan bahwa matematika itu sulit, akibat nyata yang ditemui adalah kemampuan siswa 
dalam pelajaran matematika yang relatif rendah. Walaupun matematika itu sulit tetapi dapat di upayakan agar dapat di pahami oleh semua siswa. Matematika tetap diberikan di sekolah karena kegunaannya dalam kehidupan sehari-hari.

Matematika merupakan salah satu pelajaran yang dianggap sulit hingga perlu rasanya untuk dapat meningkatkan motivasi siswa. Siswa yang bermotivasi tinggi dalam berprestasi dibidang matematika tercermin dari kemampuan siswa menalar dan berpikir secara deduktif dan indukif. Motivasi merupakan salah satu yang dapat mempengaruhi prestasi belajar siswa. Siswa yang mempunyai motivasi berprestasi tinggi dalam mengerjakan tugas-tugas di sekolah cenderung mengalami kesuksesan.

Kata "motif" [1], Diartikan sebagai daya upaya yang mendorong seseorang untuk melakukan sesuatu. Bahkan motif dapat diartikan sebagai suatu kondisi intern(kesiapsiagaan). Berawal dari kata "motif" itu, maka motivasi dapat diartikan sebagai daya penggerak yang telah menjadi aktif. Motif menjadi aktif pada saat-saat tertentu, termasuk bila kebutuhan untuk mencapai tujuan sangat dirasakan/mendesak.

Menurut Mc. Donald [1], motivasi adalah perubahan energy dalam diri seseorang yang ditandai dengan munculnya "feeling" dan didahului dengan tanggapan terhadap adanya tujuan. Dari pengertian yang dikemukan Mc. Donald ini mengandung tiga elemen penting. Bahwa motivasi itu mengawali terjadinya perubahan energy pada diri tiap individu. Perkembangan motivasi akan membawa beberapa perubahan energy di dalam system "neurophysiological" yang ada pada organisme manusia. Motivasi ditandai dengan munculnya, rasa/"feeling", afeksi seseorang. Dalam hal ini motivasi relevan dengan persoalan-persoalan kejiwaan, afeksi dan emosi yang dapat menentukan tingkah laku manusia. Motivasi akan dirangsang karena adanya tujuan. Motivasi memang muncul dari dalam diri manusia, tetapi munculnya karena terdorong oleh adanya unsur lain, dalam hal ini adalah tujuan.

Untuk dapat meningkatkan prestasi belajar matematika diantaranya dengan beberapa strategi pembelajaran. Sehingga perlu juga dikaji faktor - faktor yang dapat mempengaruhi motivasi berprestasi matematika. Secara umum motivasi berprestasi matematika dikelompokkan menjadi yaitu factor internal dan factor eksternal. Factor internal diantaranya adalah kecerdasan numerik dan konsep diri.

Kemampuan numerik yaitu kemampuan memahami hubungan angka dan memecahkan masalah yang berhubungan dengan konsep-konsep bilangan. [1]. Dengan kata lain kemampuan numerik dapat diartikan kemampuan berhitung, kemampuan menalar angka-angka, menggunakan atau memanipulasi relasi angka dan mengurainya secara logis. Pada proses belajar mengajar yang berlangsung di kelas, siswa dituntut dengan aktivitas mendengarkan, memperhatikan dan mencerna pelajaran yang diberikan oleh guru. Dalam perkembangannya kegiatan belajar mengajar saat ini berorientasi pada siswa (student center), jika siswa tidak terlibat aktif maka siswa akan mengalami kesulitan dalam proses belajar dikelas.

Oleh karena itu, kemampuan numerik siswa di sekolah sangatlah penting. Kemampuan numerik dapat diketahui melalui tes kemampuan numerik. Subtes kemampuan numerik menggungkap bagaimana baiknya seseorang memahami ide-ide yang diekspresikan dalam bentuk angka-angka dan bagaimana jelasnya 
seseorang dapat berpikir dan menalar dengan angka-angka.

Konsep diri merupakan salah satu hal terpenting yang dapat mempengaruhi kehidupan seseorang. Konsep diri adalah gagasan tentang diri sendiri yang mencakup keyakinan, pandangan dan penilaian sesesorang terhadap dirinya sendiri.[1]. Konsep diri merupakan salah satu faktor internal dan juga merupakan suatu fondasi yang sangat penting untuk keberhasilan seseorang. Konsep diri dapat terbentuk dari suatu pengalaman seseorang yang didapat baik dari keluarga, lingkungan maupun ketika disekolah.

Prestasi penulisaan ini diharapkan dapat memberikan sumbangan terhadap peningkatan kuantitas dan kualitas pembelajaran , khususnya Matematika. Dengan meningkatnya kecerdasan numerik akan memiliki dampak terhadap motivasi berprestasi di bidang matematika.

\section{METODE}

Penelitian ini dilaksanakan pada SMP Muhammadiyah di Kecamatan Tebet. Sedangkan objek penelitian dalam hal ini adalah siswa kelas IX SMP Muhammadiyah di kecamatan Tebet tahun pelajaran 2015/2016. Penelitian ini di mulai pada bulan November 2015 di SMP Muhammadiyah di Tebet Timur Tahun Pelajaran 2015/2016.

Metode penelitian yang dipakai adalah metode penelitian survey. dengan menggunakan tehnik analisis korelasional dan regresi, yaitu mencari hubungan dan pengaruh antara dua variabel bebas dengan satu variabel terikat. Metode ini memberikan gambaran tentang variabelvariabel yang ditemukan, sekaligus menyelidiki hubungan dan pengaruh antara variabel, karena itu metode ini akan mengungkapkan data faktual berdasarkan informasi yang ditemukan.

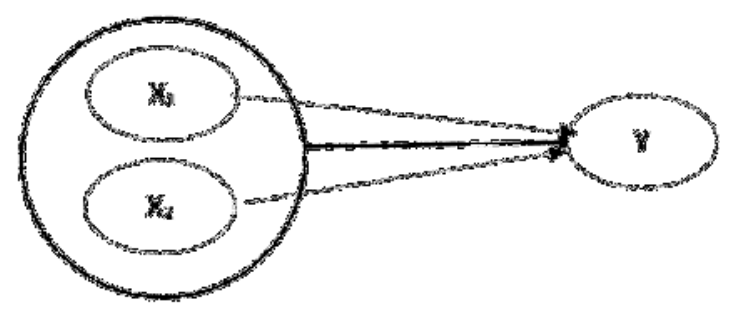

Sumber : Sugiyono 2016

Gambar 1 :Desain Penelitian

Keterangan :

$\mathrm{X}_{1}$ : Kecerdasan Numerik

$\mathrm{X}_{2}$ : Konsep Diri

$\mathrm{Y}$ : Motivasi Berprestasi Matematika

Sampel yang digunakan dari populasi 542 maka diperoleh jumlah 94 orang . Adapun anggota sampel yang digunakan oleh peneliti meliputi siswa dari 2 sekolah SMP Muhammadiyah yang terdapat di kecamatan Tebet.

Tehnik sampling adalah pengambilan sampel dimana setiap anggota populasi mendapatkan kesempatan yang sama untuk menjadi anggota sampel. Peneliti dalam penelitian ini menggunakan tekhnik Proporsional Cluster Random Sampling, dimana jumlah sampel dari setiap sekolah diambil secara proporsional berdasarkan perbandingan jumlah siswa setiap sekolah terhadap jumlah populasi keseluruhan.

Teknik analisis data menggunakan analisis regresi ganda dengan menghitung deskriptif data dan uji persyaratan analisis data meliputi uji normalitas, uji multikolinearitas dan uji linearitas.

\section{HASIL DAN PEMBAHASAN}

Setelah data penelitian terkumpul, maka dilakukan pengolahan data dengan menggunakan statistik deskriptif.

\section{Deskripsi Hasil Penelitian}

\section{A. Deskripsi Data Motivasi Berprestasi} (Y)

Data skor variabel Motivasi berprestasi matematika dikumpulkan dengan metode 
pemberian angket yang terdiri dari 20 butir pernyataan. Berdasarkan pengolahan dengan program SPSS 22 diperoleh hasil: mean $($ rata-rata $)=72,43$; standar deviasi $=$ 10,196 ; varian $=103,996$.

\begin{tabular}{ccc}
\multicolumn{2}{c}{ Tabel 1. Skor } & Motivasi Berprestasi \\
\hline Interval skor & Kategori & Frekuensi \\
\hline$X \leq 36,75$ & Rendah & 14 \\
$36,75 \leq X \leq$ & Sedang & 30 \\
68,5 & & \\
$X \geq 68,5$ & Tinggi & 50 \\
\hline
\end{tabular}

Rentang skor ini menunjukkan bahwa motivasi berprestasi siswa beragam. Dan terlihat pula bahwa siswa SMP swasta di kecamatan Tebet mempunyai motivasi berprestasi matematika yang tergolong tinggi. Motivasi berprestasi dapat berfungsi sebagai pendorong seseorang untuk melakukan keinginan yang dilandasi adanya tujuan mencapai prestasi yang baik [2]. Dengan demikian motivasi berprestasi dapat mendorong pencapaian hasil belajar termasuk dalam bidang matematika.

\section{B. Deskripsi Data Kecerdasan Numerik $\left(\mathrm{X}_{1}\right)$}

Data skor variable kecerdasan numerik dikumpulkan dengan metode pemberian soal pilihan ganda terdiri dari 26 butir soal. Berdasarkan pengolahan dengan program SPSS 22 diperoleh hasil; jumlah data (N) yang diolah sebanyak 94; mean (rata-rata) $=18,62$; standar deviasi $=3,852$; varian $=$ 14,841 ; skor minimum $=7$; skor maksimum $=26$. Skor tersebut menunjukkan bahwa kecerdasan numerik siswa tergolong tinggi.

Tabel 2. Skor Kecerdasan Numerik

\begin{tabular}{ccc}
\hline Interval Skor & Kategori & Frekuensi \\
\hline $\mathrm{X} \leq 8.5$ & Rendah & 19 \\
$8.5 \leq \mathrm{X} \leq 17.5$ & Sedang & 35 \\
$\mathrm{X} \geq 17.5$ & Tinggi & 50 \\
\hline
\end{tabular}

\section{Deskripsi Data Konsep Diri $\left(\mathbf{X}_{2}\right)$}

Data skor variabel konsep diri dikumpulkan dengan metode pemberian angket yang terdiri dari 25 butir pernyataan. Berdasarkan pengolahan dengan program SPSS 22 diperoleh hasil; jumlah data $(\mathrm{N})$ yang diolah sebanyak 94; mean (rata-rata) $=81,15$; standar deviasi $=13,647$; varian $=186,236$; skor minimum $=51$; skor maksimum $=124$. Konsep diri siswa SMP swasta di kecamatan Tebet ini tergolong rendah.

Tabel 3. Skor Konsep Diri

\begin{tabular}{ccc}
\hline Interval Skor & Kategori & Frekuensi \\
\hline$X \leq 45$ & Rendah & 14 \\
$45 \leq X \geq 85$ & Sedang & 60 \\
$X \geq 85$ & Tinggi & 30 \\
\hline
\end{tabular}

II. Pengujian Persyaratan Analisis Data A. Uji Normalitas Data

Selanjutnya dilakukan uji normalitas data, uji normalitas adalah uji yang dilakukan untuk mengecek apakah data penelitian berasal dari populasi yang sebarannya normal.

Tabel 4. Pengujian Normalitas

\begin{tabular}{llccc}
\hline & & $\mathrm{X} 1$ & $\mathrm{X} 2$ & $\mathrm{Y}$ \\
\hline $\mathrm{N}$ & & 94 & 94 & 94 \\
Normal & Mean & 18.6 & 81.15 & 72.43 \\
& & 2 & & \\
Parameters ${ }^{\mathrm{a}}$, & Std. & 3.85 & 13.64 & 10.19 \\
$\mathrm{~b}$ & Deviatio & 2 & 7 & 6 \\
& $\mathrm{n}$ & & & \\
Most & Absolute & .064 & .067 & .090 \\
Extreme & Positive & .064 & .067 & .066 \\
Differences & Negative & -.057 & -.038 & -.090 \\
Kolmogorov-Smirnov Z & .617 & .648 & .870 \\
Asymp. Sig. (2-tailed) & .841 & .795 & .435 \\
\hline \multicolumn{4}{l}{ Sumber : analisis data }
\end{tabular}

Dari pengolahan data dengan program SPSS diperoleh;

a. Variabel motivasi berprestasi matematika (Y) diperoleh angka sig. 0,435 lebih besar dari 0,05, maka Ho diterima. Berarti data berdistribusi normal.

b. Variabel kecerdasan numerik $\left(\mathrm{X}_{1}\right)$ diperoleh angka sig. 0,841 lebih besar dari 0,05, maka Ho diterima. Berarti data berdistribusi secara normal.

c. variabel Konsep diri $\left(\mathrm{X}_{2}\right)$ diperoleh angka sig. 0,795 lebih besar dari 0,05, maka Ho diterima. Berarti data konsep diri berdistribusi secara normal. 


\section{B. Uji Linieritas}

Uji Linieritas dilakukan untuk mengetahui hubungan antar variabel yang dianalisis mengikuti garis lurus atau tidak. Berdasarkan hasil pengolahan dengan SPSS diperoleh hasil:

a. Variabel Motivasi Berprestasi Matematika (Y) atas Kecerdasan Numerik $\left(\mathrm{X}_{1}\right)$ diperoleh $\mathbf{F}$ hitung $=1,402$ dan $\mathbf{F}$ tabel $=1,77$; karena $\mathbf{F}$ hitung $<\mathbf{F}$ tabel, Sig 0,164 >0,05, maka Ho diterima, artinya regresi berpola linier.

b. Variabel Motivasi Berprestasi (Y) atas Konsep Diri $\left(\mathrm{X}_{2}\right)$ diperoleh $\mathbf{F}$ hitung $=$ 1.239 dan $\mathbf{F}$ tabel $=1,81$; karena $\mathbf{F}$ hitung $<\mathbf{F}$ tabel atau $(1,239<1,81)$, Sig 0,061 $>$ 0,05 , maka Ho diterima, artinya regresi berpola linier.

\section{Uji Multikolinearitas}

Uji multikolinearitas digunakan untuk mengetahui ada atau tidaknya penyimpangan asumsi klasik multikolinearitas, yaitu adanya hubungan linear antar variabel independen dalam model regresi. Dari output Program SPSS (Tabel Coefficients) diperoleh hasil :

a. Variabel Kecerdasan Numerik $\left(\mathrm{X}_{1}\right)$ nilai tolerance $=0,581>0,1$; atau nilai VIF $=1,722<10$ artinya tidak terjadi multikolinearitas

b. Variabel Konsep Diri $\left(\mathrm{X}_{2}\right)$ nilai tolerance $0,581>0,1$; atau nilai $\mathbf{V I F}=$ $1,722<10$ artinya tidak terjadi multikolinearitas

Hasil ini menunjukan bahwa tidak ada keterkaitan antara kecerdasan numerik dengan konsep diri.

\section{Uji Heteroskedastisitas}

Se,Uji Heteroskedastisitas digunakan untuk mengetahui ada atau tidaknya penyimpangan asumsi klasik heteroskedastatis yaitu adanya ketidaksamaan varian dari residul untuk semua pengamatan pada model regresi. Berdasarkan hasil analisis program SPSS 22 diperoleh hasil ; a. Variabel Minat Belajar $\left(\boldsymbol{X}_{\boldsymbol{I}}\right)$ nilai Sig. Unstandardized Residual 0,804 >0,05 artinya tidak terjadi problem heteroskedastisitas.

b. Variabel Kecerdasan Numerik $\left(\boldsymbol{X}_{2}\right)$ nilai Sig. Unstandardized Residual 0,436 > 0,05 artinya tidak terjadi problem heteroskedastisitas.

\section{Pengujian Hipotesis Penelitian}

Tabel 5. Hasil Uji Hipotesis

Model Summary

\begin{tabular}{ccccc}
$\begin{array}{c}\text { Mode } \\
\text { I }\end{array}$ & R & $\begin{array}{c}\text { R } \\
\text { Square }\end{array}$ & $\begin{array}{c}\text { Adjuste } \\
\text { d R } ~ \\
\text { Square }\end{array}$ & $\begin{array}{c}\text { Std. Error } \\
\text { of the } \\
\text { Estmate }\end{array}$ \\
\hline 1 & $\begin{array}{c}.695 \\
\text { a }\end{array}$ & .483 & .472 & 7.412 \\
\hline
\end{tabular}

a. Predictors : (Constant), Konsep Diri, Kecerdasan Numerik

\begin{tabular}{|c|c|c|c|c|c|c|}
\hline \multicolumn{7}{|c|}{ ANOVA $^{\mathrm{a}}$} \\
\hline & & $\begin{array}{l}\text { Sum of } \\
\text { Squares }\end{array}$ & $\mathrm{df}$ & $\begin{array}{l}\text { Mean } \\
\text { Square }\end{array}$ & $\mathrm{F}$ & $\begin{array}{c}\mathrm{Sig} \\
.\end{array}$ \\
\hline \multirow[t]{3}{*}{1} & $\begin{array}{l}\text { Regress } \\
\text { ion }\end{array}$ & $\begin{array}{c}4670.1 \\
43\end{array}$ & 2 & $\begin{array}{c}2335.0 \\
71\end{array}$ & $\begin{array}{c}42.5 \\
08\end{array}$ & $\begin{array}{c}.00 \\
0^{\mathrm{b}}\end{array}$ \\
\hline & $\begin{array}{l}\text { Residu } \\
\text { al }\end{array}$ & $\begin{array}{c}4998.8 \\
36\end{array}$ & 91 & 54.932 & & \\
\hline & Total & $\begin{array}{c}9668.9 \\
79\end{array}$ & 93 & & & \\
\hline
\end{tabular}

a. Dependent Variable:Motivasi Berprestasi Matematika b.Predictors:(Constant),Konsep Diri,Kecerdasan Numerik

\begin{tabular}{|c|c|c|c|c|c|c|}
\hline \multicolumn{7}{|c|}{ Coefficients $^{\mathrm{a}}$} \\
\hline $\begin{array}{l}\text { Mo } \\
\text { del }\end{array}$ & & $\begin{array}{l}\text { Unsta } \\
\text { ndard } \\
\text { ized } \\
\text { B }\end{array}$ & $\begin{array}{l}\text { Coeffic } \\
\text { ients } \\
\text { Std. } \\
\text { Error }\end{array}$ & $\begin{array}{l}\text { Standa } \\
\text { rdized } \\
\text { Coeffi } \\
\text { cients } \\
\text { Beta }\end{array}$ & $\mathrm{t}$ & Sig \\
\hline \multirow[t]{8}{*}{1} & (Const & 32.10 & 4.738 & & 6.7 & .000 \\
\hline & ant) & 7 & & & 76 & \\
\hline & Kecerd & 1.314 & .262 & .497 & 5.0 & .000 \\
\hline & asan & & & & 21 & \\
\hline & Numeri & & & & & \\
\hline & $\mathrm{k}$ & & & & & \\
\hline & Konseo & .195 & .074 & .261 & 2.6 & .010 \\
\hline & Diri & & & & & \\
\hline
\end{tabular}

Berdasarkan angka-angka statistik Table. diatas ditemukan koefisien determinan $\left(\mathbf{R}^{2}\right)=0,483$. Koefisien determinan digunakan untuk mengetahui seberapa besar kontribusi variabel-variabel bebas terhadap variabel terikat. Berdasarkan tabel diperoleh koefisien determinan $\left(\mathbf{R}^{2}\right)$ 
$=0,483$ ini berarti bahwa pengaruh kecerdasan numerik dan konsep diri terhadap motivasi berprestasi sebesar 48,3 $\%$ sedangkan sisanya $51,7 \%$ dipengaruhi variabel lain. Pengaruh kecerdasan numerik dan konsep diri siswa secara bersama-sama dengan motivasi berprestasi matematika adalah searah, positif, dan angkanya cukup tinggi.

Berdasarkan angka statistik pada Tabel diatas menunjukan bahwa $\mathbf{F}$ hitung $=42,508$ sedangkan $\mathbf{F}$ tabel $=3,09\left(\alpha=5 \%, \mathrm{dk}_{1}=2\right.$, dan $\left.\mathrm{dk}_{2}=91(100)\right)$, maka $\mathbf{F}$ hitung $>\mathbf{F}$ tabel atau $(42,508>3,09)$, maka disimpulkan tolak $\mathrm{H}_{0}$, artinya ada signifikansi pengaruh kemampuan numerik dan konsep diri siswa secara bersama-sama terhadap motivasi berprestasi matematika. Simpulan yang sama dapat kita peroleh dari perbandingan nilai Sig. dengan taraf signifikansi $(\alpha=$ 0,05); diperoleh Sig. 0,000, karena 0,000< 0,05 , maka disimpulkan tolak $\mathrm{H}_{0}$, yang artinya ada signifikansi pengaruh kemampuan numerik dan konsep diri siswa secara bersama-sama terhadap motivasi berprestasi matematika.

Berdasarkan angka-angka statistic pada Table Coefficients ${ }^{\text {a }}$ diatas peroleh nilai Sig $=0.000$ dan $\mathbf{t}_{\text {hitung }}=5,021$, sedangkan $\mathbf{t}_{\text {tabel }}$ $=1,980$. Karena nilai $\mathbf{S i g}<0,05$ dan $\mathbf{t}_{\text {hitung }}$ $>\mathbf{t}_{\text {tabel }}$ maka $\mathrm{H}_{0}$ ditolak yang berarti terdapat pengaruh yang signifikan variabel bebas $\mathrm{X}_{1}$ (Kecerdasan Numerik) terhadap variabel terikat $\mathrm{Y}$ (Motivasi Berprestasi Matematika).

Dari hasil pengujian regresi tersebut maka bisa disimpulkan bahwa terdapat pengaruh signifikan variabel bebas $\mathrm{X}_{1}$ (Kecerdasan Numerik) terhadap variabel terikat $Y$ (Motivasi Berprestasi Matematika).

Berdasarkan angka-angka statistic pada Table Coefficients ${ }^{\mathrm{a}}$ diatas diperoleh nilai Sig $=0.010$ dan $\mathbf{t}_{\text {hitung }}=2,643$, sedangkan $\mathbf{t}_{\text {tabel }}=1,980$. Karena nilai Sig $<0,05$ dan $\mathbf{t}_{\text {hitung }}>\mathbf{t}_{\text {tabel }}$ maka $\mathrm{H}_{0}$ ditolak yang berarti terdapat pengaruh yang signifikan variabel bebas $\mathrm{X}_{2}$ (Konsep Diri) terhadap variabel terikat Y (Motivasi Berprestasi Matematika).

Dari hasil pengujian regresi tersebut maka bisa disimpulkan bahwa terdapat pengaruh signifikan variabel bebas $\mathrm{X}_{2}$ (Konsep Diri) terhadap variabel terikat $\mathrm{Y}$ (Motivasi Berprestasi Matematika).

Dapat disimpulkan bahwa Motivasi dapat diartikan sebagai kekuatan (energi) seseorang yang dapat menimbulkan tingkat persistensi dan entusiasmenya dalam melaksanakan suatu kegiatan, baik yang bersumber dari dalam diri individu itu sendiri (motivasi intrinsik) maupun dari luar individu (motivasi ekstrinsik). Seberapa kuat motivasi yang dimiliki individu akan banyak menentukan terhadap kualitas perilaku yang ditampilkannya diantaranya dalam konteks belajar. Dalam kegiatan belajar, motivasi dapat dikatakan sebagai keseluruhan daya penggerak di dalam diri siswa yang menimbulkan kegiatan belajar. Siswa yang mempunyai motivasi kuat, akan mempunyai banyak energy untuk melakukan kegiatan belajar. Motivasi siswa dalam berprestasi terhadap pelajaran matematika akan dapat dicapai bila ada 1) Kecerdasan numerik merupakan kecerdasan dalam menangkap serta mengolah data dan angka. Orang-orang dengan kecerdasan numerik yang tinggi, mampu membaca angka-angka sama jelasnya dengan membaca hurup. Kecerdasan numerik yang terdapat pada diri siswa dapat mempengaruhi prestasi siswa. Kecerdasan ini merupakan kecerdasan yang dimiliki siswa yang bersifat khusus, berhubungan dengan angka-angka dan dapat diamati ketika siswa mengerjakan soal matematika. 2). konsep diri yang dapat mempengaruhi dan meningkatkan motivasi berprestasi siswa 
dibidang matematika, dimana siswa yang mempunyai konsep diri yang kuat, ia akan belajar dengan senang dan gembira serta perhatiannya terpusat pada materi yang sedang dipelajari, lebih giat, dan akhirya mencapai prestasi yang diinginkan.

Dari informasi kuantitatif dan teori tersebut peneliti berkesimpulan bahwa Kecerdasan Numerik dan Konsep Diri berpengaruh secara bersama-sama terhadap Motivasi Berprestasi Matematika siswa. Siswa yang mempunyai konsep diri yang kuat dan positif akan termotivasi untuk berprestasi. Penuh semangat menyelesaikan tugastugas sekolah. Siswa yang mempunyai kecerdasan numerik yang tinggi akan sangat bersemangat mengikuti pelajaran matematika. Maka jika siswa memiliki konsep diri yang kuat dan positif juga memiliki kecerdasan numerik yang tinggi, siswa tersebut akan sangat termotivasi untuk berprestasi dibidang matematika.

Dapat pula disimpulkan bahwa konsep diri dapat mempengaruhi kualitas pencapaian hasil belajar siswa dalam bidang studi tertentu, konsep diri akan menyebabkan pemusatan perhatian yang intensif terhadap materi pelajaran, kegiatan pembelajaran, ditandai dengan lebih giat belajar, dan akhirya mencapai prestasi yang diinginkan. Konsep diri merupakan kondisi psikologis dalam diri manusia yang dapat membangkitkan gairah siswa dan menyebabkan ia menggunakan waktu, energi, perhatian, dorongan, kreativitas untuk mencapai cita-cita yang terkait dengan konsep-konsep dasar matematika. Siswa yang memiliki konsep diri akan cenderung berusaha untuk lebih aktif, berusaha memahami konsep dan prinsip objek yang dipelajari.

Pengertian diatas cukup jelas menerangkan bahwa konsep diri mempunyai hubungan dan dapat mempengaruhi serta meningkatkan perhatian siswa terhadap motivasi untuk berprestasi dalam bidang matematika, jika siswa mempunyai konsep diri dan motivasi yang kuat maka siswa akan belajar dengan senang dan gembira serta perhatiannya terpusat pada materi yang sedang dipelajari, lebih giat, dan akhirya mencapai prestasi yang diinginkan. Dari informasi kuantitatif dan teori tersebut peneliti berkesimpulan bahwa Konsep Diri berpengaruh terhadap Motivasi Berprestasi Matematika siswa.

\section{SIMPULAN}

Berdasarkan analisis data, pembuktian hipotesis penelitian dan pembahasan hasil penelitian, maka penelitian tentang pengaruh kecerdasan numerik dan konsep diri siswa terhadap motivasi berprestasi matematika, yang dilakukan pada siswasiswi kelas IX SMP Muhammadiyah di Kecamatan Tebet, Jakarta Selatan dapat disimpulkan bahwa:

1. Terdapat pengaruh signifikan kecerdasan numerik dan konsep diri siswa secara bersama-sama terhadap motivasi berprestasi matematika siswa kelas IX SMP Muhammadiyah di wilayah Kecamatan Tebet, Jakarta Selatan.

2. Terdapat pengaruh signifikan kecerdasan numerik terhadap Motivasi Berprestasi Matematika siswa kelas IX SMP Muhammadiyah di wilayah Kecamatan Tebet, Jakarta Selatan.

3. Terdapat pengaruh signifikan Konsep Diri terhadap Motivasi Berprestasi Matematika siswa kelas IX SMP Muhammadiyah di wilayah Kecamatan Tebet, Jakarta Selatan.

4. Dalam [5] terdapat pengaruh positif dan signifikan kecerdasan numerik terhadap prestasi belajar matematika. Dengan strategi yang tepat siswa terdorong dan bersemangat sehingga termotivasi untuk berprestasi dibidang matematika seiring dengan meningkatnya kecerdasan numerik. 
5. Dalam [5] secara teoritis motivasi berprestasi merupakan pendorong atau penggerak yang berasal dari dalam diri siswa untuk melakukan aktifitas belajar guna mencapai tujuan. Siswa yang memiliki motivasi berprestasi tinggi cenderung mengalami kesuksesan dalam mengerjakan tugas-tugas di sekolah.

6. Dalam [5] konsep diri sangat berpengaruh dalam menentukan sikap siswa dalam hal motivasi berprestasi. Pandangan individu mengenai bagimana diri individu merupakan landasan kepercayaan diri yang dibangun individu terhadap dirinya sendiri yang akan mempengaruhi performa individu tersebut dalam berprestasi . ketika seseorang individu yakin akan kemampuannya tentunya akan kemampuannya tentunya akan mendorong individu untuk semakin berprestasi . namun apabila individu memandang negatif kemampuan pada dirinya maka individu tersebut akan merasa bahwa dirinya tidak mampu untuk berprestasi sehingga dalam diri individu tersebut kurang memiliki motivasi berprestasi. Oleh karena itu konsep diri memegang peran dalam memunculkan motivasi berprestasi.

\section{DAFTAR PUSTAKA}

[1] Desmita. Psikologi Perkembangan Peserta Didik. Bandung : PT Remaja Rosdakarya. 2009.

[2] Ki Fudyartanta. Tes Bakat dan Perskalaan Kecerdasan. Yogyakarta : Pustaka Pelajar. 2004.

[3] A. M. Sadiman. Interaksi \& Motivasi. Belajar Mengajar. Jakarta : PT Raja Grafindo Persada. 2014.

[4] Slameto. Belajar dan Faktor-Faktor Yang Mempengaruhi. Jakarta : Rineka Cipta. 2013

[5] Supardi, U. S. Aplikasi Statistika Dalam Penelitian. Jakarta : Ufuk Press. 2012.
[6] Muh. Jamil, Hamzah Upu, Muhammad Darwis M. Jurnal : "Pengaruh Kemampuan Numerik, Kecerdasan Emosional, dan Menghapal Al Quran terhadap Prestasi Belajar Matematika Santri Pesantren Se-Kota Watampone”. Jurnal. Program Studi Pendidikan Matematika. Program Pascasarjana. Universitas Negeri Makasar.

[7] Nur Prima Septiana : “ Hubungan Antara Konsep Diri Dengan Motivasi Berprestasi Pada Siswa SMA Negeri 3 Sragen." . Skripsi. Fakultas Psikologi. Universitas Muhammadiyah Surakarta. 2014.

[8] Arvyaty, Faad Maonde, Naimin Noho : "Pengaruh Motivasi Berprestasi Terhadap Prestasi Belajar Matematika Siswa SMA Negeri dan SMA Swasta di Kota Kendari." Jurnal. Program Study Pendidikan Matematika. FKIP UHO. 